Pesq. Vet. Bras. 36(9):844-850, setembro 2016

DOI: $10.1590 / \mathrm{S} 0100-736 \mathrm{X} 2016000900009$

\title{
Immunocytochemical characterization of primary cell culture in canine transmissible venereal tumor ${ }^{1}$
}

\author{
Luis M.M. Flórez ${ }^{2,3 *}$, Haline F. Ballestero², Anderson P. Duzanski ${ }^{2,4}$, Paulo R.O. \\ Bersano $^{5,6}$, João F. Lima ${ }^{6}$, Fernanda L. Cruz ${ }^{7}$, Ligia S. Mota ${ }^{8}$ and Noeme S. Rocha ${ }^{2}$
}

\begin{abstract}
Flórez L.M.M., Ballestero H.F., Duzanski A.P., Bersano P.R.O., Lima J.F., Cruz F.L., Mota L.S. \& Rocha N.S. 2016. Immunocytochemical characterization of primary cell culture in canine transmissible venereal tumor. Pesquisa Veterinária Brasileira 36(9):844-850. Programa de Pós-Graduação em Medicina Veterinária, Faculdade de Medicina Veterinária e Zootecnia, Universidade Estadual Paulista, Distrito de Rubião Junior s/n, Botucatu, SP 18618-970, Brazil. E-mail: maomontoya53@yahoo.es

Immunochemistry with anti-vimentin, anti-lysozyme, anti-alpha 1 antitrypsin, anti-CD3 and anti-CD79 $\alpha$ antibodies has been used for characterization of primary cell culture in the transmissible venereal tumor (TVT). Samples for primary cell culture and immunohistochemistry assays were taken from eight dogs with cytological and clinical diagnosis of TVT. To validate the immunochemical results in the primary cell culture of TVT, a chromosome count was performed. For the statistical analysis, the Mann-Whitney test with $\mathrm{p}<0.05$ was used. TVT tissues and culture cells showed intense anti-vimentin immunoreactivity, lightly to moderate immunoreactivity for anti-lysozyme, and mild for anti-alpha-antitrypsin. No marking was achieved for CD3 and CD79 $\alpha$. All culture cells showed chromosomes variable number of 56 to 68 . This is the first report on the use of immunocytochemical characterization in cell culture of TVT. Significant statistic difference between immunochemistry in tissue and culture cell was not established, what suggests that the use of this technique may provide greater certainty for the confirmation of tumors in the primary culture. This fact is particularly important because in vitro culture of tumor tissues has been increasingly used to provide quick access to drug efficacy and presents relevant information to identify potential response to anticancer medicine; so it is possible to understand the behavior of the tumor.
\end{abstract}

INDEX TERMS: Canine transmissible venereal tumor, alpha 1 antitrypsin, cytogenetic, lysozyme, vimentin.

\footnotetext{
${ }^{1}$ Received on January 8, 2015.

Accepted for publication on April 8, 2016.

${ }^{2}$ Departamento de Clínica Veterinária, Faculdade de Medicina Veterinária e Zootecnia, Universidade Estadual Paulista (Unesp), Campus de Botucatu, Distrito de Rubião Jr, Botucatu, SP 18618-000, Brazil.

${ }^{3}$ Grupo de Pesquisa em Patologia Veterinária, Faculdade de Ciências Agropecuárias, Universidade de Caldas, Manizales, Colombia. * Corresponding author: maomontoya53@yahoo.es

${ }^{4}$ Departamento de Patologia, Faculdade de Medicina de Botucatu, Unesp-Botucatu, Distrito de Rubião Jr, Botucatu, SP 18618-000, Brazil.

${ }^{5}$ Faculdade de Medicina Veterinária, Universidade Estadual do Ceará, Av. Barão de Studart 505, Meireles, Fortaleza, CE 60120-013, Brazil

${ }^{6}$ Centro de Estudo de Venenos e Animais Peçonhentos (CEVAP), Unesp-Botucatu, Rua José Barbosa de Barros 1780, Fazenda Experimental Lageado, SP 18610-307, Brazil.

${ }^{7}$ Biotecnologia Animal, Faculdade de Medicina Veterinária e Zootecnia, Unesp-Botucatu, Distrito de Rubião Jr, Botucatu, SP 18618-000, Brazil.

${ }^{8}$ Laboratório de Genética Animal, Instituto de Biociências, Unesp-Botucatu, Distrito de Rubião Jr, Botucatu, SP 18618-000, Brazil.
}

RESUMO.- [Caracterização imunocitoquímica de culturas primárias de tumor venéreo transmissível canino.] Os anticorpos anti-vimentina, anti-lisozima, anti-alfa 1 antitripsina, anti-CD3 e anti-CD79 $\alpha$ foram empregados para a caracterização de culturas primárias de tumor venéreo transmissível canino (TVT). Amostras para cultura primária e imuno-histoquímica foram coletadas de oito cães com diagnóstico clínico e citológico de TVT. Para validar o resultado inmunocitoquímico nas culturas de TVT foi realizada a contagem de cromossomos. Para a análise estatística o teste de Mann-Whitney foi empregado a um nível de significância de $\mathrm{p}<0.05$. As culturas e os tecidos de TVT apresentaram intensa reatividade para vimentina, moderada a leve para Lisozima, moderada para alfa-antitripsina e não houve marcação para CD3 e CD79 $\alpha$. Finalmente, todas as culturas apresentaram números de cromossomos que variaram de 56 a 68. Este é o primeiro relato que apresenta 
o uso da immunocitoquímica para a caracterização de culturas de TVT. Assim, e devido ao fato de se observar semelhança entre a imunomarcação em células e tecidos, sugere-se que o uso desta técnica possa auxiliar na confirmação de culturas primárias do tumor, fato muito importante porque a utilização da cultura do tumor pode permitir o acesso a informação relevante sobre resposta potencial a um tratamento e conhecimento do comportamento biológico do tumor.

TERMOS DE INDEXAÇÃO: Tumor venéreo transmissível canino, alfa 1 antitripsina, citogenética, lisozima, vimentina.

\section{INTRODUCTION}

Transmissible venereal tumor (TVT) is a contagious and sexually transmissible neoplasm of unknown origin. In natural conditions, TVT only affects dogs. However, other species can be infected by its experimental induction. It was first studied in 1876 by Novinsky and later by Smith \& Washbourn (Marchal et al. 1997, Rogers 1997, MacEwen 2001, Oliveira et al. 2013). Since that time, TVT has been described as a transmissible and transplantable tumor (Booth 1994, Hasler \& Weber 2000, Rebbeck et al. 2009, Strakova \& Murchison 2015).

This neoplasm has spread in dogs worldwide, but a major prevalence is located in tropical and subtropical climates (Ferreira et al. 2000, Varaschin et al. 2001), mainly in countries with large populations of mongrel street dogs (Papazoglou et al. 2001, Strakova \& Murchison 2014).

The transference of TVT among dogs has been found to be equal, regardless gender, either by implantation of viable tumor cells in mucous membranes during coitus, or by scratching, licking, biting or smelling of a carrier animal (Varaschin et al. 2001, Ganguly et al. 2013, Sreekumar et al. 2015). Besides genital contact, TVT also may have an extra-genital localization (Pereira et al. 2000, Rodrigues et al. 2001, Albanese et al. 2002, Siddle \& Kaufman 2013). TVT usually is restricted to the points of origin and implantation of the disease, except in rare cases, around 2.5\% (Pandey et al. 1989), in which it invades adjacent tissues, lymphatic and/or blood circulation, and reaches distant areas such as lungs, liver, spleen, brain and other organs as metastatic deposits (Meuten 2002, Maxie 2007, Ganguly et al. 2013, Strakova \& Murchison 2014).

Moreover, multiple subcutaneous masses have been reported (Kroger et al. 1991). The tumor has a unique behavior showed by the usual occurrence of spontaneous regression in adults. However, in newborns and immunocompromised dogs, it becomes metastatic and, consequently, fatal (Cohen 1973, Yang \& Jones 1973, Ganguly et al. 2013).

In previous studies conducted at the Laboratory of Investigative Pathology of the College of Veterinary Medicine and Zootechny (FMVZ Botucatu), some TVT presented fewer DNA breaks (Amaral et al. 2011), larger nucleolar sizes (Amaral 2005) and high reactivity of Ki-67 (MBI-1). This points towards an intense proliferation of neoplastic cells (Gaspar 2005), higher rates of metastases (Amaral et al. 2007) and increased expression rates of p-glycoprotein (Gaspart et al. 2010).
According to Bassani-Silva et al. (2007), upon exposing TVT cells to extracts of propolis in vitro, some became resistant. Likewise, when comparing malignant cell response to chemotherapy, TVT cells were significantly less sensitive to this treatment (Gaspar et al. 2009, 2010).

In this case, such features could be an indication of different forms of TVT presentation (Fonseca et al. 2012), which leads to the conclusion that there are differences between the cell types present (Roger et al. 1998, Montoya et a. 2012), with variable biological behavior (Rogers et al. 1998). This also demonstrates the need for a specific treatment for each tumor, which would minimize cost and collateral effects by avoiding the excessive administration of chemotherapy.

Thereby, a direct consequence of the above mentioned is the higher number of chemotherapy applications required to obtain initial regression (Gaspar et al. 2010). This results in higher costs for owners and more side effects, such as anorexia, myelosuppression and nephrotoxicity, for the animals. Therefore, further research is required to confirm the hypothesis related to this condition.

Primary cell culture is one of the fastest ways to study TVT behavior. Studies based on experimental primary cell cultures are consistent with similar situations next to in vivo, which differ from those observed in immortalized cell lines represented by uniform cells with well-defined characteristics. (Loukopoulos et al. 2004, Hasegawa et al. 2008, Jähn et al. 2010). In this respect, studies on TVT could help to advance in the research of molecular events associated with initiation, progression and chemotherapy.

However, despite the existence of studies on primary cell culture of TVT, there are still no published studies showing the characterization and the identification of tumor cells in vitro through immunological techniques. For this reason, the present study aims to isolate and characterize primary cell culture of TVT by immunocitochemistry, contributing especially towards studies related to tumorigenesis and chemotherapy resistance of these tumors in in vivo models.

\section{MATERIALS AND METHODS}

The study was approved by the Ethics Committee on Animal Experimentation of the Veterinary Medicine College, São Paulo State University (Unesp), Brazil (Protocol 223/2011). Eight dogs with cytological and clinical diagnosis of TVT were selected from the Hospital of Veterinary Medicine, UNESP, regardless of breed, gender and age.

Cytological preparations of tumors were fixed and then stained by the Giemsa technique (May Grünwald Giemsa 2\%). A minimum of 100 cells per slide (2) were analyzed by light microscopy at 400-x magnification for tumor diagnosis and classification, according to the characteristics of the predominant cell type, namely plasmocytoid, lymphocytoid, or mixed, as described by Amaral et al. 2007. Once the diagnosis of TVT had been confirmed, the animals were anesthetized for total cleansing of the tumor site and two samples were collected by incisional biopsy, obtaining fragments of approximately $1 \mathrm{~cm}^{3}$. Two samples were taken from each dog, one for cell culture and the other for immunohistochemistry assays. Specimen owners were informed about the study procedures. All samples were taken from patients before undergoing chemotherapy. The samples were stored in saline and phos- 
Table 1. Primary antibodies and dilutions used in the immunostaining protocols for the characterization of TVT

\begin{tabular}{|c|c|c|c|c|c|}
\hline Antibody & Code & Dilution ratio & Epitope retrieval (HIER) & Manufacturer & Type of antibody \\
\hline Anti-CD79a & A045201-2 & $1: 100$ & \multirow{5}{*}{$\begin{array}{l}\text { Pascal chamber } \\
\text { citrate buffer } \\
\text { solution } \\
\text { (pH 6.0) }\end{array}$} & Dako, EUA & Monoclonal \\
\hline Anti-CD3 & A045201-2 & $1: 100$ & & Dako, EUA & Polyclonal \\
\hline Anti-Lysozyme & A009902-2 & $1: 300$ & & Dako, EUA & Polyclonal \\
\hline Anti-Alpha-1-Antitrypsin & N153330-2 & $1: 300$ & & Dako, EUA & Polyclonal \\
\hline Anti-vimentin & U7034 & $1: 100$ & & Dako, EUA & Monoclonal \\
\hline
\end{tabular}

phate solution (PBS) pH 7.4 and formaldehyde (Qiagen ${ }^{\circledR}$, Venlo, Limburg, Netherlands) until the material was processed.

Primary cell culture. Insulations of TVT cultures were made according to the protocol described by Bassani-Silva et al. 2007 and Hsiao et al. 2008. Therefore, aseptic fragments of TVT, placed in saline PBS pH 7.4 (Invitrogen, Life Technology, Waltham, Massachusetts, USA), were transported to the Laboratory for in vitro Fertilization and Cellular Cultures in the Department of Animal Reproduction and Veterinary Radiology FMVZ-Unesp, Botucatu Campus. There, the samples were ground using a stainless steel scalpel. Afterwards, the material was transferred to a trypsin solution (TrypLE Select-Invitrogen-Life Technology, Waltham, Massachusetts, USA) at $37.5^{\circ} \mathrm{C}$ and kept for 40 minutes with a magnetic homogenizer, after which the solution was passed through a 70 micron filter (70 microns Falcon ${ }^{\circledR}$ cell strainers, Corning, NY). Cells resulting from this process were placed in a falcon tube over a Percoll gradient to $42 \%$ (Amersham Pharmacia Biotech, Piscataway, NJ) and subsequently centrifuged $\left(820 \mathrm{~g}, 4^{\circ} \mathrm{C}, 25 \mathrm{~min}\right)$. TVT cells located in the air-liquid interphase were collected and the pellet was suspended and conditioned in $25 \mathrm{~cm}^{2}$ flasks (Sarstedt, Germany) with $5 \mathrm{~mL}$ of DMEM high glucose culture (Dulbecco's modified essential medium-Gibco). This material was supplemented with $10 \%$ fetal calf serum (FCS) (Gibco Life Technologies, Waltham, Massachusetts, USA) and a combination of $100 \mathrm{U} / \mathrm{ml}$ penicillin, 100mg /ml streptomycin (Life Technologies Gibco ${ }^{\circledR}$, Waltham, Massachusetts, USA) and $3 \mu \mathrm{g} / \mathrm{ml}$ amphotericin B (Life Technologies Gibco ${ }^{\circledR}$, Waltham, Massachusetts, USA). The initial purity was confirmed by Hemacolor (Merck, Whitehouse Station, NJ, USA). The samples were then kept in a $\mathrm{CO}_{2}$ incubator at $5 \%$, moisture $95 \%$ and a temperature of $37.5^{\circ} \mathrm{C}$. Cell viability and concentration were assessed by an exclusion test using trypan blue and the cells were suspended in DMEM high glucose culture (Dulbecco’s essential medium modified-Gibco ${ }^{\circledR}$ Life Technologies, Waltham, Massachusetts, USA).

Immunohistochemistry and immunocytochemistry. Serial histological sections of $3 \mu \mathrm{m}$ were obtained in positive charged slides $\left(\right.$ Amitel $^{\circledR}$ ), which were deparaffinized in xylene and rehydrated in decreased ethanol concentrations. Tissue sections were exposed to heat in a Pascal chamber (Dako ${ }^{\circledR}$ Cytomation) with citrate buffer solution ( $\mathrm{pH} 6.0$ ) at $125^{\circ} \mathrm{C}$ for $30 \mathrm{~s}$ in order to induce them to epitope retrieval (HIER). The slides were rinsed three times with Tris pH7.0. They were then incubated overnight by using anti-lysozyme, anti-Alpha-1-antitrypsin, anti-CD3, antiCD79 $\alpha$ primary antibodies (Table 1 ). The resulting reaction was visualized with a polymer-based technology HiDef ${ }^{\circledR}$ Detection HRP System (Cell Marque ${ }^{\circledR}$ ). The slides were revealed with chromogen 3,3'-diaminobenzidine (DAB). They were then counter-stained by using Harris hematoxylin.
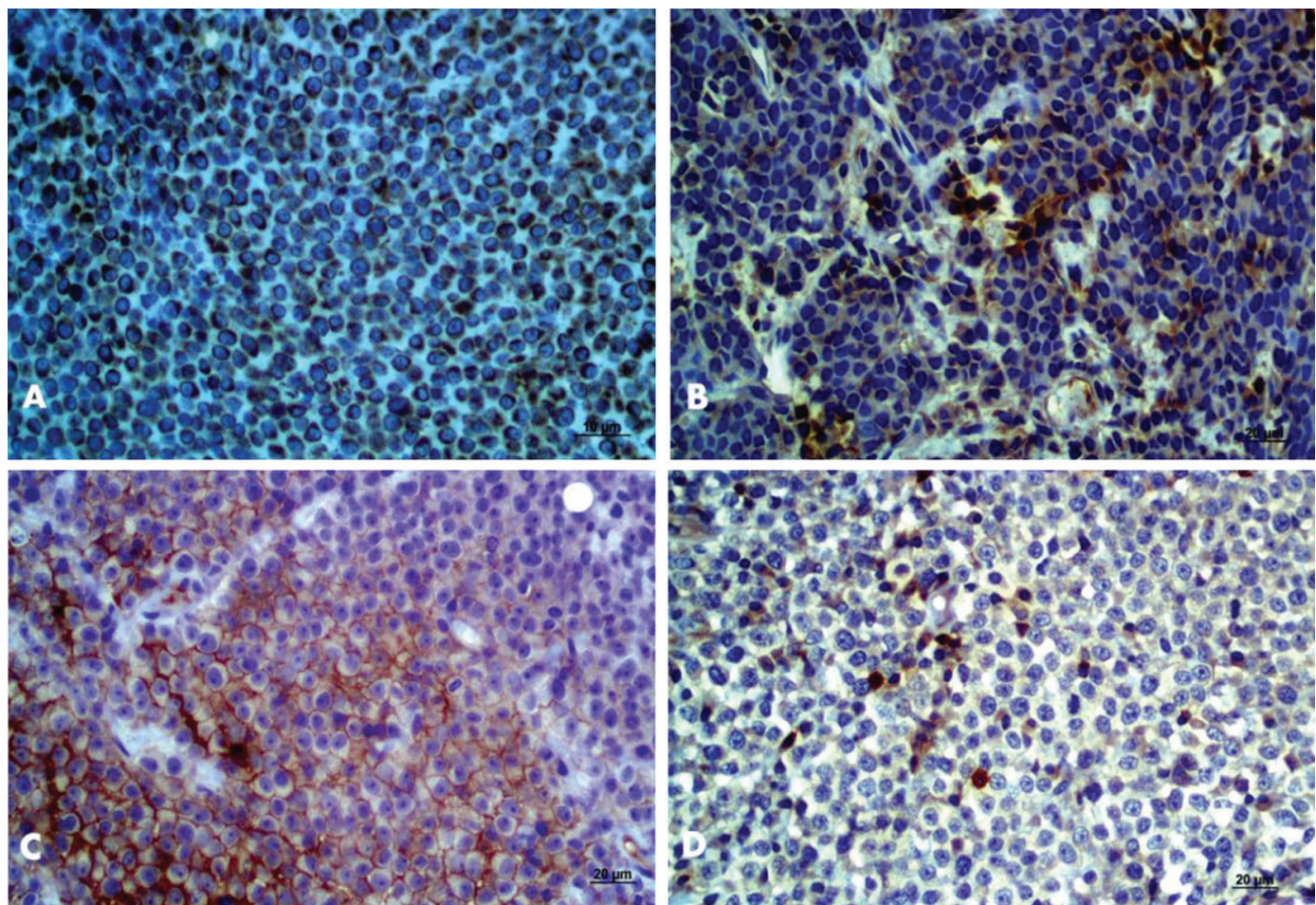

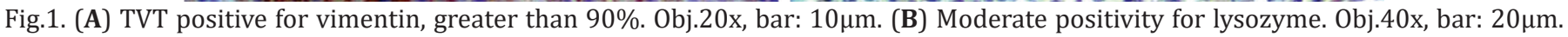
(C) Moderate positivity for alpha-antitrypsin. Obj.40x, bar: $20 \mu \mathrm{m}$. (D) Lack of tumor cell positivity for CD3, CD79 $\alpha$ (See lymphocyte marking). Obj.40x, bar: $20 \mu \mathrm{m}$. HiDef ${ }^{\circledR}$ Detection HRP System; Chromogen 3'3 diaminobenzidine (DAB), counterstaining with Harris hematoxylin. 
Immunocytochemistry. Immunocytochemistry assays were performed on cell culture, first hydrated and permeabilized and then, after blocking the endogenous peroxidase, the immunochemical steps were conducted.

Negative controls were prepared by substituting specific primary antibodies with antibody diluent (Novocastra ${ }^{\circledR}$ ). Positive controls were set with liver for anti-Lysozyme, anti-Alpha-1-Antitrypsin and lymph node for anti-CD3 and anti-CD79 $\alpha$, and heart for anti-vimentin marking.

To identify and quantify the expression of the reaction rate, samples were subjected to a semi-quantitative evaluation method as follows: $1=<25 \%$ labeled cells, $2=26-50 \%, 3=51-75 \%, 4=$ $>75 \%$, were considered, respectively, $1=$ unmarked, 2 = slightly marked, 3 = moderate, and finally, 4 = with intense marking. One hundred cells were counted for each slide (Amaral 2005).

Images were captured with a Carl Zeiss optical microscope, Lab.A1, Germany, obj.10x and 40x, and processed with AxioVision 4.8 software. In all cases, two veterinary pathologists made the immunohistochemistry evaluation. For each slide, 10 fields were read with 400x magnification. Inter-observer variation was resolved by simultaneous dual re-evaluation.
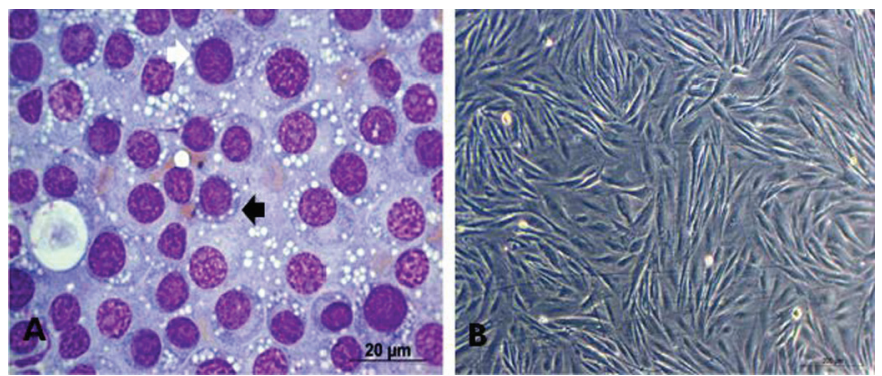

Fig.2. (A) TVT cells, lymphocytoid standard (round cells, little cytoplasm and high nucleus:cytoplasm ratio), black arrow. Standard plasmacytoid (ovoid cells, broad cytoplasm and eccentric nuclei) white arrow obj.40x. (B) TVT cell culture, third passage. Bar: $200 \mu \mathrm{m}$.
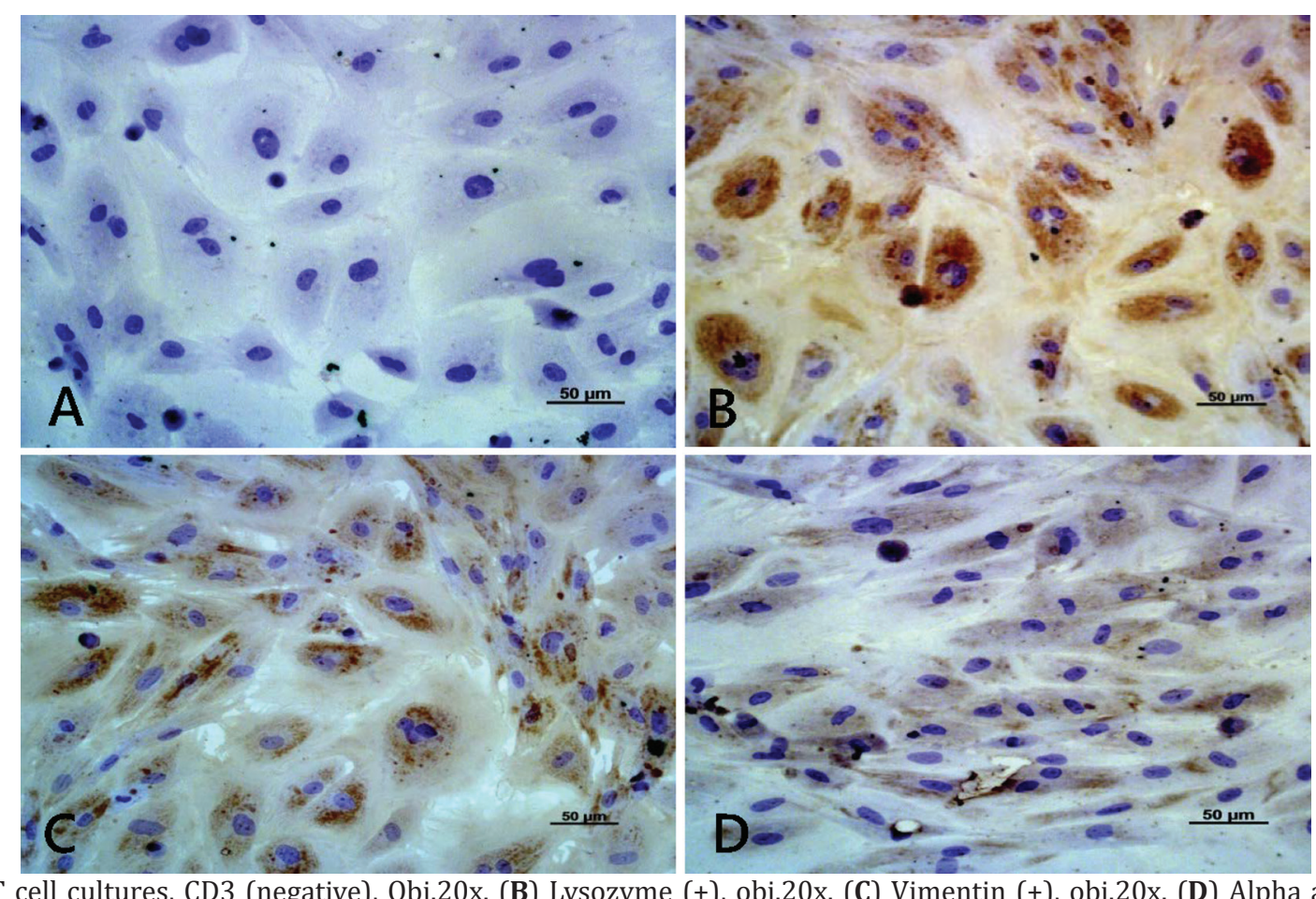

Fig.3. (A) TVT cell cultures, CD3 (negative), Obj.20x. (B) Lysozyme (+), obj.20x. (C) Vimentin (+), obj.20x. (D) Alpha antitrypsin (+), HiDef ${ }^{\circledR}$ Detection HRP System; Chromogen 3'3 diaminobenzidine (DAB), Harris hematoxylin counterstaining, obj.20x, bar: 50 $\mu$ m.
Cytogenetic analysis. To validate the immunochemical results on primary cell culture of TVT, a chromosome count was conducted. Colchicine was added at a final concentration of 0.2 $\mathrm{Mg} / \mathrm{mL}$ after 18 hours of incubation. Following two hours of reincubation, cells were harvested by treatment based on a versene solution. Cell cultures were then treated with a hypotonic citrate solution. Air-dried preparations were created and stained with $2 \%$ acetic orcein and, finally, examined.

Statistical analysis. The comparison of the immunohistochemistry in tissue and the immunocytochemistry in the cell culture was done by using the Mann-Whitney test with $\mathrm{p}<0.05$.

\section{RESULTS}

The TVT tissues showed intense anti-vimentin immunoreactivity, greater than $90 \%$ of the cells. The anti-lysozyme immunoreactivity was $79 \%$ of the total labeled tissue, being lightly moderate in $29 \%$ and $50 \%$. In the case of anti-alpha-antitrypsin, 55\% had mild tissue marking. Finally, no marking was obtained for CD3 and CD79 $\alpha$ (Fig.1A-D, Fig.4)

On the other hand, eight cultures, one from each dog, were isolated (Fig.2). All showed positive anti-vimentin marking in $100 \%$ of cases, of which $75 \%$ of the cells presented intense immunoreactivity and $25 \%$ moderate immunoreactivity. For lysozyme, $87 \%$ of the cultures were marked, with $25 \%$ mild and $62 \%$ moderate. For alpha-antitrypsin, $75 \%$ of the cultures had mild marking.

Finally, all cultures were negative for CD3 and CD79 $\alpha$ (Fig.3A-D, Fig.6). There were no statistical differences between the immunohistochemical and the immunocytochemical expression ( $\mathrm{p}>0.05)$.

The cells showed a variable number of chromosomes between the cultures isolated; 56 to 68 . None of them exhibited the same number of somatic cells characteristic of dogs, as demonstrated in Fig.5. 


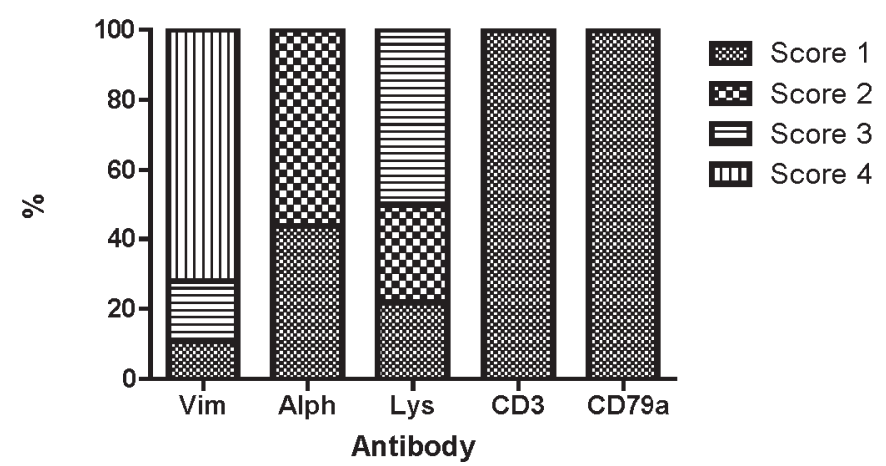

Fig.4. Distribution of the immunoreactivity levels for the antibody panel used to characterize TVT tissues. Vim = Anti-vimentin; Alph = Anti-Alpha-1-Antitrypsin; Lys = Anti-Lysozyme. Score 1= unmarked; 2 = slightly marked; 3 = moderate; 4 = intense marking.

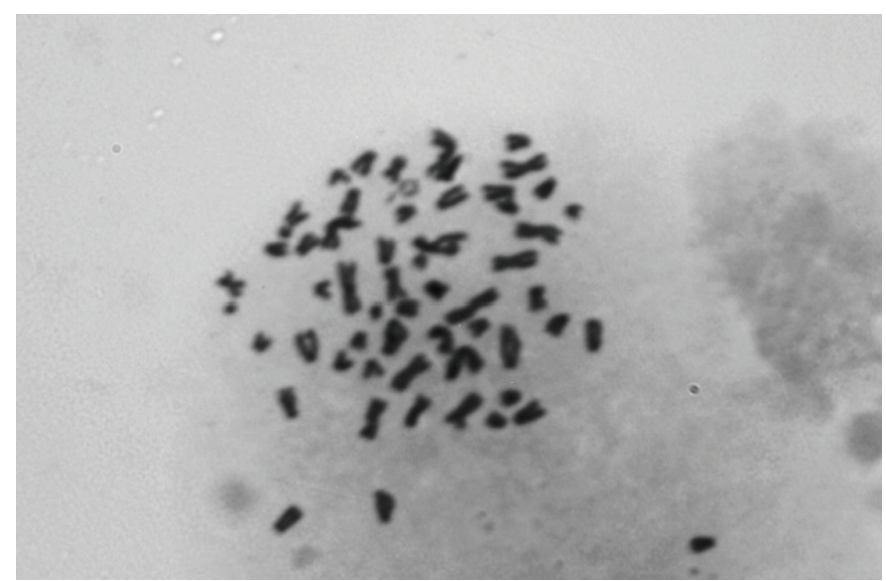

Fig.5. TVT metaphases in cell culture. Chromosome number is less than 78. In this case 58.

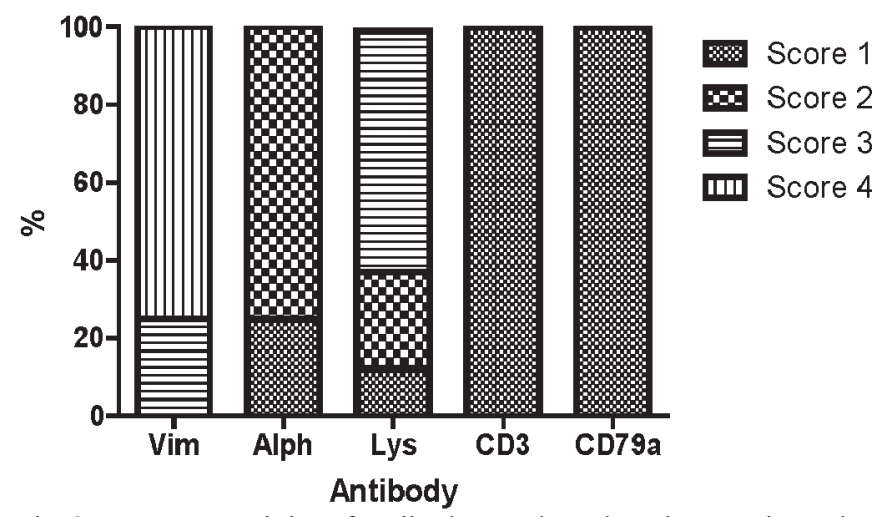

Fig.6. Immunoreactivity of antibody panel used to characterize cultured TVT cells. Vim $=$ Anti-vimentin; Alph $=$ Anti-Alpha-1-Antitrypsin; Lys = Anti-Lysozyme. Score 1= unmarked; 2 = slightly marked; 3 = moderate; $4=$ intense marking.

\section{DISCUSSION}

The TVT has been subject of several studies over the time. However, further research is still needed to better identification of mechanisms related to its strength and aggressiveness (Montoya et al. 2014).

In vitro culture of tumor tissues is especially an interesting model to identify and evaluate tumor biology because cells retain certain characteristics of tissue in vivo. Moreo- ver, the system provides quick access to drug efficacy and presents relevant information to identify potential response as anticancer medicine in the complex microenvironment of tumor tissue (Van der Kuip et al. 2006, Mitra et al. 2013).

The TVT primary culture provides an opportunity to study mechanisms and extrapolate different elements of information about the tumor in vivo. Thus, in the present study, an antibody panel was used to assist in the identification of primary tumor cultures. In summary, eight primary cultures were set to these purposes.

Once isolated, the entire primary culture must be characterized in TVT. Despite having been isolated several times (Adams et al. 1968, Mohanty \& Rajya 1977, Beschorner et al. 1979, Okamoto et al. 1988, Bassani-Silva et al. 2007), the identification of such tumor cells is based on the establishment of cell karyotype (Oshimura et al. 1973, Mukaratirwa \& Gruys 2003). Inmunocytochemistry was used in this research to define possibilities of identifying isolated cells from tumor as belonging to itself.

From a clinical point of view, TVT cells have been usually characterized through markers such as vimentin, lysozyme, alpha-antitrypsin (Moore \& Rosin 1986, Sandusky et al. 1987, Mozos et al. 1996, Marchal et al. 1997, Pereira et al. 2000, Morris et al. 2002, Mukaratirwa \& Gruys, 2003, Araújo et al. 2012, Mascarenhas et al. 2014). For this reason, these antibodies were firstly considered to characterize TVT primary cultures.

At first, the chosen panel showed compatibility to the results reported in the scientific literature (Pereira et al. 2000, Morris et al. 2002, Mukaratirwa \& Gruys 2003, Araújo et al. 2012, Mascarenhas et al. 2014). In fact, the phenotypic profile presented by the authors to identify the TVT cells can be considered as an auxiliary method in the definitive diagnosis of the tumor.

When compared primary cultures to inmunocytochemical features of TVT, a similar statistical profile of tissues was observed. Moreover, expression of vimentin and alpha-antitrypsin lysozyme enables to identify cells coming from TVT, as described in the literature, since these markers have helped in a high number of cases to establish a differential diagnosis (Mozos et al. 1996, Mukaratirwa \& Gruys 2003).

In TVT tissues, the use of such markers excluded other types of round cell tumors, such as lymphomas, melanomas, amelanotic melanomas, poorly differentiated carcinomas, and mastocitomas. However, some authors described similar immunostaining in histiocytomas. In this case, differential diagnosis is based on clinical and histopathological criteria (Mozos et al. 1996, Ramos-Vara et al. 2008).

Finally, analyzed tissues and cells of TVT displayed no immunoreactivity for CD3 and CD79 $\alpha$. Nevertheless, concerning tissues, lymphocyte immunostaining was observed during tumor inflammatory infiltration. Data already observed in other studies also support this issue (Mozos et al. 1996, Marchal et al. 1997, Mukaratirwa \& Gruys 2003, Araújo et al. 2012.).

In the cultures, marking for these antibodies was not found. This was expected because in cultures "in vitro", lymphocytes and other inflammatory cells lack adhesion, being deleted during the change of medium. 
To validate the immunostaining results in primary cultures, the karyotype of TVT cells was assessed. At the end, in all cases, chromosome number resulted less than 78, which was characterized as TVT cells.

These data corroborate what different authors describe: the chromosome number in TVT cell cultures may present a wide variation between 46 and 67 (Adams et al. 1968, Oshimura et al.1973, Mukaratirwa \& Gruys 2003, Murchison et al. 2014). Therefore, the results allowed concluding that isolated cells are from TVT.

Likewise, the authors of this research consider these findings as innovative and unpublished, also highlighting the antibody panel as a useful tool for TVT primary cultures to identify cells as coming from the same tumor. These finding would eventually contribute to veterinary oncology investigation.

\section{CONCLUSIONS}

This paper is the first report on the use of immunocytochemistry in cell culture of TVT. This fact is particularly important, because in vitro culture of tumor cells has been increasingly used to provide quick access to drug efficacy, and presents relevant information to identify potential response to anticancer medicine.

It is possible to understand the behavior of the tumor. However, significant statistical difference between immunochemistry in tissue and cell culture was not established yet, what suggests that the use of this technique may provide greater certainty in confirmation of the tumor in primary cell culture.

Acknowledgements.- Financial Support: Foundation of support to the research of São Paulo State (FAPESP Proc:2012/19285-2).

\section{REFERENCES}

Adams E.W., Carter L.P. \& Sapp W.J. 1968. Growth and maintenance of the canine venereal tumor in continuous culture. Cancer Res., Baltimore, 28:753-757.

Albanese F., Poli A. \& Millanta F. 2002. Primary cutaneous extragenital canine transmissible venereal tumour with Leishmania-laden neoplastic cells: a further suggestion of histiocytic origin? Vet. Dermatol. 13:243246.

Amaral A.S., Bassanil-Silva S., Ferreira I., Fonseca L.S., Andrade F.H., Gaspar L.F. \& Rocha N.S. 2007. Cytomorphological characterization of transmissible canine venereal tumor. Revta Port. Ciênc. Vet. 103:563-564.

Amaral A.S., Ferreira I., Colodel M.M., Fávero D.M. \& Rocha N.S. 2011. DNA damage in canine transmissible venereal tumor. Revta Lusit. Ciênc. Med. Vet. 4:1-5.

Amaral A.S. 2005. Tumor venéreo transmissível canino: critérios citológicos de malignidade e caracterização citomorfológica correlacionada a imunocitoquímica e lesões de DNA. Tese de Doutorado em Medicina Veterinária, Faculdade de Medicina Veterinária e Zootecnia, Universidade Estadual Paulista, Botucatu. 228p.

Araújo M.R., Preis I.S., Lavalle G.E., Cassali G.D. \& Ecco R. 2012. Histomorphological and immunohistochemical characterization of 172 cutaneous round cell tumours in dogs. Pesq. Vet. Bras. 32(8):772-780.

Bassani-Silva S., Sforcin J.M., Amaral A.S. \& Rocha N.S. 2007. Propolis effect in vitro on canine transmissible venereal tumour cells. Revta Port. Ciênc. Vet. 102:261-265.

Beschorner W.E., Hess A.D., Nerenberg S.T. \& Epstein R.B. 1979. Isolation and characterization of canine venereal tumor-associated inhibitory and blocking factors. Cancer Res., Baltimore, 39(10):3920-3927.
Booth M.J. 1994. Canine transmissible venereal tumour and ovarian papillary cystadenocarcinoma in a bitch. J. Small Anim. Pract. 35(1)39-42.

Cohen D. 1973. The biological behavior of the canine transmissible venereal tumour in imunosupressed dogs. Eur. J. Cancer 9:253-258.

Ferreira A.J., Jaggy A. \& Varejão A.P. 2000. Brain and ocular metastases from a transmissible venereal tumour in a dog. J. Small Anim. Pract. 41(4):165-168.

Fonseca L.S., Mota L.S., Colodel M.M. \& Rocha N.S. 2012. Spontaneous canine transmissible venereal tumor: association between different phenotypes and the insertion LINE-1/c-myc. Revta Colomb. Cienc. Pecu. $25: 402-408$

Ganguly B., Das U. \& Das K. 2013. Canine transmissible venereal tumour: a review. Vet. Comp. Oncol. 11(4):1-12.

Gaspar L.F., Amaral A.S., Bassani-Silva S. \& Rocha N.S. 2009. Imunorreatividade à glicoproteína-p nos diferentes tipos citomorfológicos de tumor venéreo transmissível canino. Veterinária em Foco 6(2):140-146.

Gaspar L.F., Ferreira I., Colodel M.M. \& Rocha N.S. 2010. Spontaneus canine transmissible venereal tumour: cell morphology and influence on p-glycoprotein expression. Turkish J. Vet. Anim. Sci. 34:447-454.

Gaspar L.F.J. 2005. Caracterização citomorfológica do tumor venéreo transmissível canino correlacionada com danos citogenéticos, taxa de proliferação e resposta clínica à quimioterapia. Universidade Estadual Paulista, Tese de Doutorado em Medicina Veterinária, Faculdade de Medicina Veterinária e Zootecnia, Botucatu, SP. 143p.

Hasegawa Y., Shimada K. \& Suzuki N. 2008. The in vitro osteogenic characteristic of primary osteoblastic cells from a rabbit calvarium. J. Oral Sci. 50:427-434

Hasler A.H. \& Weber W.T. 2000. Theriogenology question of the month. Transmissible venereal tumour (TVT). J. Am. Vet. Med. Assoc. 216(10): 1557-1559. (Errata: Theriogenology question of the month. J. Am. Vet. Med. Assoc. 217(1):42).

Hsiao Y.W., Liao K.W., Chung T.F., Liu C.H., Hsu C.D. \& Chu RM. 2008. Interactions of host IL- 6 and IFN-gamma and cancer-derived TGF-beta1 on MHC molecule expression during tumor spontaneous regression. Cancer Immunol. Immunother. 57:1091-104.

Jähn K., Richards R., Archer C. \& Stoddart M. 2010. Pellet culture model for human primary osteoblasts. Eur. Cells Mater. 20:149-161.

Kroger D., Grey R.M. \& Boyd J.W. 1991. An usual presentation of canine transmissible venereal tumour. Canine Pract. 16 (6):17-21.

Loukopoulos P., O'brien T., Ghoddusi B.A., Mungall D. \& Robinson W.F. 2004. Characterisation of novel canine osteosarcoma cell lines producing high levels of matrix metalloproteinases. Res. Vet. Sci.77:131-141.

MacEwen E.G. 2001. Transmissible veneral tumour, p.651-656. In: Withrow S.J. \& MacEwen E.G. (Eds), Small Animal Clinical Oncology. 3rd ed. W.B. Saunders, Philadelphia.

Marchal T., Chabanne L., Kaplanski C., Rigal D. \& Magnol J.P. 1997. Immunophenotype of the canine transmissible venereal tumour. Vet. Immunol. Immunopathol. 57(1/2):1-11.

Mascarenhas M.B., Peixoto P.V., Ramadinha R.R., Yamasaki E.M., Costa S.Z., Driemeier D., Sonne L. \& França T.N. 2014. Immunohistochemical study of genital and extragenital forms of canine transmissible venereal tumor in Brazil. Pesq. Vet. Bras. 34(3):250-254.

Maxie G. 2007. Nervous system, p.283-485. In: Ibid. (Ed.), Jubb K.V.F., Kennedy P.C. \& Palmer N., Pathology of Domestic Animals. Vol.1. 5th ed. Elsevier Saunders, Edinburgh.

Meuten D.J. 2002. Tumours in Domestic Animals. 4th ed. University of California Press, London, p.115-117, 435, 572.

Mitra A., Mishra L. \& Li S. 2013. Technologies for deriving primary tumor cells for use in personalized cancer therapy. Trends Biotechnol. 31(6): 347-354.

Moore P.F. \& Rosin A. 1986. Malignant histiocytosis of Bernese mountain dogs. Vet. Pathol. 23(1):1-10.

Mohanty G.C. \& Rajya B.S. 1977. Growth and morphological characteristics of canine venereal tumor cell in vitro. Vet. Path.14(4):420-425.

Montoya F.L., Pedraza F.J., Grandi F. \& Rocha N. 2012. Cytologic subtypes of canine transmissible venereal tumor. Vet. Clin. Pathol. 41(1):4-5. 
Montoya L.M., Feo H.B. \& Rocha N.S. 2014. Tumor venéreo transmissível canino: expressão dos genes MDR-1, TP53 e da família Bcl-2 implicações no comportamento biológico e terapêutico. Ver. CES Med. Vet. Zootec. 2:277-290.

Morris J.S., Mcinnes E.F., Bostock D.E., Hoather T.M. \& Dobson J.M. 2002. Immunohistochemical and histopathologic features of 14 malignant fibrous histiocytomas from flat-coated retrievers. Vet. Pathol. 39:479-499.

Mozos E., Méndez A., Gómez-Villamandos J.C., Martín De las Mulas J. \& Pérez J. 1996. Immunohistochemical characterization of canine transmissible venereal tumor. Vet. Pathol. 33:257-263.

Mukaratirwa S. \& Gruys E. 2003. Canine transmissible venereal tumor: cytogenetic origin, immunophenotype, and immunobiology. A review. Vet. Quart. 25(3):101-111.

Murchison P.E., Wedge D.C., Alexandrov L.B., Fu B., Martincorena I., Ning Z., Tubio J., Werner E., Allen J., Barboza De Nardi A., Donelan E., Marino G., Fassati A., Campbell P., Yang F., Burt A., Weiss R. \& Stratton M. 2014. Transmissable dog cancer genome reveals the origin and history of an ancient cell lineage. Science 343(6169):437-440.

Okamoto Y., Fujinaga T. \& Tajima M. 1988. Isolation and cultivation of canine transmisible sarcoma cells. Jap. J. Vet. Sci. 50(1):9-13.

Oliveira D.K., Quessada A.M., Medeiros S.M., Lima C.F., Dos Santos L.S., Alves de Pinho F. \& Barbosa L.R. 2013. Transmissible Venereal Tumor Treated with Autohemotherapy. Acta Scient. Vet. 41:1107.

Oshimura M., Sasaki M. \& Makino S. 1973. Chromosomal banding patterns in primary and transplanted venereal tumors of the dog. J. Natl Cancer Inst. 51:1197-1203.

Pandey S.K., Chandrapuria V.P., Bhargava M.K. \& Tiwari S.K. 1989. Incidence, treatment approach and metastasis of canine transmissible venereal sarcoma. Indian J. Anim. Sci. 59:510-513.

Papazoglou L.G., Koutinas A.F. \& Plevraki A.G. 2001. Primary intranasal Transmissible Venereal Tumour in the dog: a retrospective study of six spontaneous cases. J. Vet. Med. A 48(7):391-400.

Pereira J.S., Silva A.B. \& Martins A.L. 2000. Immunohistochemical characterization of intraocular metastasis of a canine transmissible venereal tumour. Vet. Ophthalmol. 3(1):43-47.
Ramos-Vara J.A., Kiupel M., Baszler T., Bliven L., Brodersen B., Chelack B., Czub S., Piero F.D., Dial S., Ehrhart E.J., Grahan T., Manning L., Paulsen D., Valli V.E. \& West K. 2008. Suggested guidelines for immunohistochemical techniques in veterinary diagnostic laboratories. J. Vet. Diagn. Invest. 20:393-413.

Rebbeck C.A., Thomas R., Breen M., Leroi A.M. \& Burt A. 2009. Origins and evolution of a transmissible cancer. Evolution 63(9):2340-2349.

Rodrigues G.N., Alessi A.C \& Laus J.L. 2001. Intraocular transmissible venereal tumour in a dog. Ciência Rural 31(1):141-143.

Rogers K.S. 1997. Transmissible venereal tumor. Compend. Contin. Educ. Pract. Vet. 19(9):1036-1045.

Rogers K.S., Walker M.A. \& Dillon H.B. 1998. Transmissible venereal tumour: a retrospective study of 29 cases. J. Am. Anim. Hosp. Assoc. 34(6): 463-470.

Sandusky G.E., Carlton W.W. \& Wightman K.A. 1987. Diagnostic immunohistochemistry of canine round cell tumors. Vet. Pathol. 24(6):495-499.

Siddle H.V. \& Kaufman J. 2013. A tale of two tumours: comparison of the immune escape strategies of contagious cancers. Mol. Immunol. 55:190193.

Sreekumar K.S., Narendran P.V. \& Ajidhan V.B. 2015. Case Study of Canine Transmissible Venereal Tumor. EC Veterinary Science. p.109-117.

Strakova A. \& Murchison E.P. 2014. The changing global distribution and prevalence of canine transmissible venereal tumour BMC Vet. Res.10:168.

Strakova A. \& Murchison E.P. 2015. The cancer which survived: insights from the genome of an 11000 year-old cancer. Curr. Opin. Genet Dev. 30:49-55.

Yang T.J. \& Jones J.B. 1973. Canine transmissible venereal sarcoma: transplantation studies in neonatal and adult dogs. J. Natl Cancer inst. 51:1915-1918.

Van der Kuip H., Mürdter T.E., Sonnenberg M., McClellan M., Gutzeit S., Gerteis A., Simon W., Fritz P. \& Aulitzky W.E. 2006. Short term culture of breast cancer tissues to study the activity of the anticancer drug taxol in an intact environment. BMC Cancer 6(86):1-11.

Varaschin M.S., Wouters F. \& Bernis V.M. 2001. Tumor venéreo transmissível canino na região de Alfenas, Minas Gerais; formas de apresentação clínico-patológicas. Clín. Vet. 6(32):32-38. 